\title{
The Effect of Inflation on The Currency Exchange Rate Seen in The Islamic Finance
}

\author{
Agus Purnomo \\ Ekonomi Syariah, Fakultas Studi Islam Uniska MAB \\ guspur80@gmail.com
}

\begin{abstract}
The exchange rate is defined as the currency that can be exchanged as one unit of another currency, or the value of currency with another currency. When the circulating money in community is too much, then inflation may happen. Inflation is the increasing of goods price continuously. This does not mean that the prices of various goods increase at the same percentage. The increase which happened only once is not called inflation, although rising prices reach considerable percentage. The aim of the research is to determine the effect of inflation on the value of rupiah in Indonesia in the Islamic finance. This research used quantitative and qualitative methods. In quantitative method, the writer used data analysis of Indonesia monetary policy. The data was taken from Bank of Indonesia, meanwhile for qualitative method, the writer collected the data through interview with employee of Bank of Indonesia. From inflation data analysis in 2013, it is known that inflation was 5.31\% in February, 6.7\% in June 2014, 7.26\% in 2015, and 3.60\% in 2016. The result of this research showed that the influence of inflation toward currency exchange rate in the perspective of Islamic finance occured because of export decline, the slow growth of economy global, the decline of world crude oil prices, coal price, palm oil price, and rubber price. As a result, those factors caused inflation to the value of the rupiah against US dollar.
\end{abstract}

Keywords: Inflation, Money Exchange and Islamic Finance

\begin{abstract}
Abstrak
Nilai tukar didefinisikan sebagai mata uang yang dapat ditukarkan sebagai satu unit mata uang lain, atau merupakan harga dari suatu mata uang dengan mata uang lain. Peredaran uang di masyarakat apabila terlalu banyak akan menyebabkan inflasi. Inflasi adalah proses kenaikan harga-harga umum barang-barang secara terus menerus. Ini tidak berarti bahwa harga-harga berbagai macam barang itu naik dengan persentase yang sama. Kenaikan yang terjadi hanya sekali saja bukanlah merupakan inflasi, meskipun kenaikan harga tersebut terjadi dengan persentase yang cukup besar. Tujuan dari penelitian ini untuk mengetahui pengaruh inflasi terhadap nilai tukar mata uang rupiah di Indonesia dalam perspektif keuangan syariah. Penelitian ini menggunakan metode penelitian kuantitatif dan kualitatif. Metode kuantitatif menggunakan analisis data kebijakan moneter keuangan Indonesia dengan menggunakan data dari Bank Indonesia untuk mengetahui kinerja perekonomian dalam keuangan syariah, sedangkan metode penelitian kualitatif menggunakan analisis wawancara dari karyawan Bank Indonesia. Data tahun 2013 menunjukkan bahwa inflasi mengalami kenaikan, pada bulan Februari menunjukan nilai Inflasi 5,31\% sampai pada periode tahun 2014 bulan Juni menunjukan nilai inflasi 6,7\%. Pada tahun 2015 mengalami Inflasi sebesar 7,26\% dan tahun 2016 mengalami
\end{abstract}


Inflasi sebesar 3,60\%. Hasil dari penelitian ini menunjukan, pengaruh inflasi terhadap nilai tukar rupiah dalam perspektif keuangan syariah terjadi karena menurunnya ekspor ke luar negeri akibat lambatnya pertumbuhan perekonomian dunia, turunya harga minyak mentah dunia, turunnya harga batubara, serta turunya harga minyak sawit dan harga karet. Faktorfaktor tersebut yang menyebabkan terjadinya inflasi terhadap nilai tukar mata uang rupiah terhadap dolar Amerika.

Kata Kunci: Inflasi, Nilai Tukar Mata Uang dan Keuangan Syariah

\section{INTRODUCTION}

Inflation is a classical problem in economic growth. The economic crisis that occurred in Indonesia in 1997 was basically started from high inflation causing the decline of currency values, and price increased in general; thus it reduced the purchasing power of the society. The phenomenon of inflation leads to misery for society, making the poor even poorer, even creating new poor people. Each country must have a certain currency value, as well as in Indonesia where the rupiah becomes the currency. It is impossible if a country does not need money, because money is a medium of exchange used to buy and sell. Money is also an asset to a country. However, government should control too much circulation of money in order to prevent inflation.

Another factor that affects exchange rate is the interest rate (BI rate). Raising or lowering the interest rate (BI rate) is one of the monetary policies undertaken by Bank of Indonesia to regulate the amount of money in circulation and maintain the stability of the rupiah exchange rate. Changes in interest rates (BI rate) will affect investment in foreign securities (Situmeang, 2010: 28). Investors who interact globally will probably look for some countries with profitable interest rates, and if the BI rate increases, foreign interest rates will relatively be unchanged. Indonesian investors will reduce the demand for US dollars as Indonesia offers more attractive rate of return, and foreign investors will offer US dollars to invest in rupiah.

Money is a legal tender used in sale and purchase transactions, and each country has its own currency which is different from one another. For this reason, the exchange rate is agreed between the two countries to exchange each currency. Currently, Indonesia is facing problem that is the decline of Indonesian rupiah over the US dollar. Rupiah exchange rate continues to decrease over the dollar. It has significant impacts on the Indonesian economy, both positive and negative impacts. United States Dollar is a standard currency throughout the world despite the fact that there are other currencies that are stronger than the US dollar that is the currency Euro (EUR) and Poundsterling (GBP).

Still, the US dollar became the main benchmark of world currencies and the main benchmark of money exchange in the world. The declining rupiah condition since late 2014 was Rp. 12,396,00 per US \$ 1 (taken on December 31, 2014). Bank of Indonesia released the exchange rate of rupiah against the dollar at the end of August 2014, and had already begun to weaken by Rp. 11,715 per US \$ 1 . According to Apriliani (2015) at the end of September 2014 the exchange rate of the rupiah against 
the dollar weakened by Rp. 12.228,00, and per October 2014 strengthened to Rp. $12,201.00$ US \$ 1 . In two months before the end of 2014, the rupiah was stagnant in position of Rp. 12,190.00 per November 2014 and at the end of December 2014 the rupiah weakened at Rp. 12,396,00. Many Indonesian economists predict that in early 2015 the rupiah would continue to weaken. Bank of Indonesia re-released the exchange rate of rupiah against the dollar at the end of January 2015, and it weakened at Rp. 12,644.00. Even in February 2015 the exchange rate of the rupiah against the dollar almost reached the point of Rp. 13.000,00 per US \$ 1 exactly Rp. 12,931.00. Indeed, as of March 31, 2015 the rupiah weakened by Rp. 13,084,00. Indonesian rupiah was getting worse against the US dollar. On April 30, 2015, rupiah exchange rate against the dollar appears to strengthen by Rp. $12,950.00$ per US \$ 1, and on May 7, 2015 , the rupiah closed at the point of Rp. 13,148.00. It was a fantastic number since Indonesia economy is in progress.

This study used primary data and secondary data. Primary data is obtained through documentation which is related to BI rate from 2012 to 2016. Secondary data is obtained in the field, results of inflation statistics in 2012-2016, the result of interviews with leaders or officials appointed at the office of Bank of Indonesia Banjarmasin. In addition, secondary data is also obtained through library research in the form of guidebooks, literature and records related to the effect of inflation on currency exchange rates viewed from Islamic finance. This research was conducted at the office of Bank of Indonesia in Banjarmasin

Based on the background of study above, the researcher would like to formulate the research questions as: (1) How rupiah exchange rate influence inflation viewed from Islamic finance perspective, (2) Factors that contribute to the decline of the Rupiah exchange rate against inflation viewed from Islamic finance perspective, and (3)How does inflation influence the BI rate in the perspective of Islamic finance.

Seeing the potential effect of inflation on the exchange rate of currency seen from the point of view of Islamic finance, the researcher wanted to know the effect of inflation on the exchange rate of currency by using a qualitative method in Indonesia economy. Based on the elaboration above, researcher would carry out a study entitled "The Effect of Inflation on the Currency Exchange Rate Seen in the Islamic Finance".

\section{LITERATURE REVIEW}

\section{Inflation in Conventional Economyy}

Inflation is the process of increasing prices of goods continuously. This does not mean that the prices of the various items increase with the same percentage. Getting increased once is not inflation, despite price increases by a sizeable percentage (Nopirin, 2007: 34).

Some economists define the meaning of inflation based on its causes and some others explain based on the consequences. According to Hasan (2012: 18) the theory of quantity, explains that inflation is an excess in the quantity of the prevailing currency, causing the excess at the general level of the price value. While based on the impact, inflation is defined as a symptom of excess at the general price level.

Based on two theories that explain about inflation, it can be understood that in- 
flation is an economic situation that occurs with the condition of the excess amount of currency in circulation compared with the value of goods and services in real terms. Therefore, since demand for goods and services is high while supply is limited, the value of the currency decreases compared to the high prices of goods or services.

The imbalance between the money circulation and the quantity of goods has led to financial inflation at that time. Based on Irvin Fisher's theory, the way to set the variables $\mathrm{M}, \mathrm{V}$, and $\mathrm{T}$ is by conducting monetary and fiscal policies or policy concerning production. According to Nopirin (2007: 38) the policies are as follows:

a. Monetary policy, the goal of monetary policy is achieved through regulating the money circulation (M). One component of money is demand deposit. The Central Bank may regulate demand deposit through minimum reserve arrangements. By raising the minimum reserves, the amount of money will become smaller. In addition, the Central Bank may also use what so-called discount rate. The discount rate for Commercial Bank is the cost for the loan provided by the Central Bank, so the commercial bank's enthusiasm to borrow is smaller, consequently the ability of the Commercial Bank to lend to the community also decreases.

b. Fiscal policy, concerning regulation of government expenditure as well as taxation that can directly affect the total demand and thus will affect the price. Inflation can be prevented through a decrease in total demand.

c. Policies related to outputs, output increase can minimize inflation. Increase in output can be achieved with the policy of decreasing import duties, so that imports increase, the number of goods increases, then the price will decrease. This is done by determining price ceiling, and basing salary or wage on a certain price index, so if the price index rises, then the salary raises.

\section{Inflation According to Islamic Perspective}

According to the Islamic economic system, under normal conditions, inflation is unlikely to happen. Although inflation is caused by war, natural disasters, such as flood and earthquake, market manipulation cannot be avoided, but in such conditions the government can develop a set of policies to stabilize prices, in addition to providing education to the community to consistently refer to sharia (Mannan, 2008: 29).

One cannot participate in creating inflation. Demand full inflation and cost push inflation in the economy always occur in a balanced way, there can be no demand for goods without the supply of money. So inflation is not caused by economic activity, but is solely attributed to the monetary policy of the government or Central Bank which has been printing excessive money, unbalanced with the amount of goods available (Mannan, 2008: 41).

Maintaining the stability of currency values is very important, then the question is how to maintain the stability of the current value of banknote? The world monetary system is now controlled by fiat money which is very vulnerable to volatile, except for some countries that still use bi-metals (dinars and dirhams). Robert A. Mundell, an economist, said that when the world's people use fiat money, their logical consequences have entered a new economic stage, the regime of permanent inflation (Hatta, 2008: 19).

In Islamic economic school, there are several opinions that explain the economic policy that can be used as a monetary instrument to overcome the problem of 
inflation, those are:

a. The first school (Iqtisaduna).In this point of view, like Muhammad Baqr as-Sadr, the Islamic economy will exist in real life in society which runs the Islamic shari'a totally. Economic problems during this time occurred because of irregularities committed by humans, such as the distribution of wealth is not balanced and the lack of thanking god for the blessings of Allah SWT (Khand, 2011).

b. The second school (Mainstream). According to this view of the school, like Chapra, the teachings of Islam explains that prices are determined by the market mechanism. It is an opportunity to realize the price in accordance with its maqasid. Demand for money in Islam should be directed to the real investment sector. According to this madzhab, pressing rate of money circulation that exceeds the amount of goods is by zakat. Because zakat limits a person to spend money on unproductive and speculative interests (Chapra, 1996: 76).

According to the second school, the demand for money can be represented by using the following equation:

$\mathrm{Md}=\mathrm{f}(\mathrm{Ys}, \mathrm{S}, \pi)$

Explanation:

Md = Deman for money

Ys $\quad=$ Goods and services

$\mathrm{S} \quad=$ Values and social institutions, including zakat

$\Pi \quad=$ Profit and lost sharing

The third school (Alternative).

According to the third school, to realize the stability of the value of the currency is to realize an integrated system of monetary with the real sector. The positive consequence of regulating the amount of money circulation in accordance with real economic conditions is to anticipate the occurrence of inflation. It also can maintain the stability of currency exchange rates. Demand and supply of money is based on the calculation of the reserve ratio between the Central Bank and Commercial Bank (Choudhury \& Hussain, 2005: 28).

\section{Factors Contribute to Exchange Rate}

According to Situmeang (2010: 43), the factors contribute to exchange rate are: a. Inflation rate

Changes in rate of inflation can affect the activities of international trade because of the different price as the impact of inflation. Changes in trading activity will affect the demand and supply of currencies that affect the exchange rate, for example if Indonesia's inflation rate is higher than the US, then the rupiah against the US dollar will weaken. The real change is caused not only by a factor such as inflation but also by a combination of various factors.

b. Interest rate

Changes in interest rates will affect investment in foreign securities so that it will affect the demand and supply of foreign currency. Investors who interact globally will look for countries with profitable interest rates. It is assumed that interest rates 
in Indonesia will rise when interest rates in the US are relatively unchanged, then investors from Indonesia will reduce the demand for US dollars as interest rates in Indonesia offer more attractive return. On the contrary, investors from America will invest their capital in Indonesia by offering US dollars to invest in rupiah.

c. Government control

Government is the party that has a very decisive position in determining exchange rates. The government has great power and sufficient capital capacity to influence the market

d. Expectations

Future expectations can drive the exchange rate as well as other financial markets. Investors will anticipate the possibility of value movements in the future. Forecasting of future changes will encourage investors to take profits with the hope of preceding the market in taking anticipatory action.

\section{Exchange Rate System.}

According to Agus (2003: 56), there are several exchange rate systems, they are:

a. Fixed exchange rate system. It is a system in which the value of a country's currency is determined by the currency of another country. This system forces the government to always adjust its exchange rate if it no longer matches the value set by devaluating its currency.

b. The floating and under control exchange rate system. In this system the central bank determines that its currency may move in certain time that has been established. If the currency moves exceeding upper and lower limits, the central bank will intervene by buying or selling US dollars. In addition to direct intervention, the government also uses other instruments such as interest rates.

c. The free floating exchange rate system, in this system the government is no longer obliged to intervene on exchange rate movements. The currency is allowed to make adjustments through market mechanisms. In addition, this system can save the country's foreign exchange reserves.

\section{The Factors Contribute to Inflation}

The following are factors contribute to inflation:

a. Demand-pull inflation

It happens because of the increase in demand for certain types of goods. In this case, people's demand is aggregated. This increase may occur because the government spent more money on buying goods, and an increase in demand for goods for private needs. This increase in public demand resulted in rising prices due to fixed bids.

b. Cost-pull inflation

This inflation happens due to an increase in production cost. Increase in production costs occurs because of rising raw prices, for example because of the success of trade unions in raising wages or due to fuel increase. The increase in production costs resulted in rising prices and inflation.

c. Inflation as the amount of money in circulation increases

This theory is proposed by the classical group that said that there is a rela- 
tionship between the amount of money in circulation and the prices. If the amount of goods remains while money supply increases then the price will rise. Increasing the amount of money in circulation can occur, for example because of printing new money that causes prices to rise.

\section{Method of Collecting Data}

Method of collecting data used in this research is interview and documentation to obtain primary and secondary data. The data is collected through:

a. Interviews, the writer conducted interview with the leader and staff of Bank of Indonesia about the effect of inflation on rupiah currency viewed from sharia finance perspective.

b. Statistical data, that is the report of rupiah exchange rate in 2012-2016 and statistical data of BI rate in 2012-2016 (www.bps.go.id/www.bi.go.id)

c. Field observation, it is done by observing the object of research about the influence of inflation toward currency exchange rate in Indonesian economy in the development of BI rate.

d. Library research and documentation, it was conducted by studying some reading materials and scientific papers, journals, documents and reports from Indonesian government and economic policies.

\section{Technique of Analyzing Data}

To analyze the data of this research, the writer used a clear concept map. The writer then interpreted and analyzed it. The writer used a qualitative and quantitative description with interactive analysis techniques (Idrus, 2010: 62).

\section{RESEARCH FINDINGS AND DISCUSSION}

\section{The Influence of Inflation toward Rupiah Exchange Rate of 2012-2016}

Table 1. The Development of Inflation in Indonesia 2012-2016

\begin{tabular}{lrrrrr}
\hline \multicolumn{1}{c}{ Month } & $\begin{array}{r}2012 \\
(\%)\end{array}$ & $\begin{array}{r}2013 \\
(\%)\end{array}$ & $\begin{array}{r}2014 \\
(\%)\end{array}$ & $\begin{array}{r}2015 \\
(\%)\end{array}$ & $\begin{array}{r}2016 \\
(\%)\end{array}$ \\
\hline Jan & 3,65 & 4,57 & 8,32 & 6,96 & 4,14 \\
Feb & 3,56 & 5,31 & 7,75 & 6,29 & 4,42 \\
Mar & 3,97 & 5,9 & 7,32 & 6,38 & 4,45 \\
Apr & 4,5 & 5,57 & 7,25 & 6,97 & 3,60 \\
May & 4,45 & 5,47 & 7,32 & 7,15 & 3,33 \\
Jun & 4,53 & 5,9 & 6,7 & 7,26 & 3,45 \\
Jul & 4,56 & 8,61 & 4,53 & 7,26 & 3,21 \\
Aug & 4,58 & 8,79 & 3,99 & 7,18 & 2,79 \\
Sep & 4,31 & 8,4 & 4,53 & 6,83 & 3,07 \\
Okct & 4,61 & 8,32 & 4,83 & 6,25 & 3,31 \\
Nov & 4,32 & 8,37 & 6,23 & 4,89 & 3,58 \\
Dec & 4,3 & 8,38 & 8,36 & 3,35 & 3,02 \\
\hline Sour
\end{tabular}

Source of Data: Bank Indonesia 2016

According to Nopirin (2007: 15) inflation is an ongoing process of increasing price. An increase in the price of one or two kinds of goods cannot be said as inflation unless the increase has an impact on the price increase of most other goods. Based on 
the economic development and circulation of money in the community, it is obviously clear that people use money as a means of transaction. If the money circulating in the community is more, it can lead to demand and supply of goods in sale and purchase transactions decreased, and inflation may happen. Based on the data taken from BPS/ Bank of Indonesia, the development of inflation in Indonesia is described as Table 1.

Based on the Table 1. it is known that in 2012 until 2016 inflation decreased. However, in 2013 inflation increased due to the American and Chinese economies was in good condition. While Indonesian economy experienced Inflation on the money exchange rate in Islamic finance, so the exchange rate of rupiah currency increased. In 2013 the inflation rate increased, in February the value of Inflation was $5.31 \%$, and up to June 2014 the value of Inflation was $6.7 \%$, this was due to the world crude oil price increased and caused the price of fuel, electricity tariff, transportation tariff, and price of staple goods increased. As stated by the Governor of Bank of Indonesia in South Kalimantan, Harimurthy Gunawan:

"The strength of the country's finances in the appreciation of the US dollar and the normalization of the Fed's policy causes pressure on currency exchange rates around the world and including the rupiah exchange rate. As an example in November 2014, the rupiah exchange rate weakened by $0.21 \%$ to Rp. 12,167 ,- the pressure of the weakening of the Rupiah exchange rate resulting from the rising of world oil prices. It encouraged government to subsidize the fuel oil price in order not to press the sharia financial system on the economic system of the State of Indonesia “.

In 2016 Sharia financial system inflation decreased because the American economy decreased as well. It is because the prices of crude oil, palm oil, coal and other minerals decreased. American and China economy experienced a decline because Indonesia's economy is very strong, and it affects the Islamic financial system. In 2016 the United States was conducting Presidential elections when the American economy was not good.

\section{The Weakening of the Rupiah Exchange Rate against the US Dollar Exchange Rate}

Money is one of the most important means of exchange in economic activity around the globe. It is a set of assets in the economy routinely used by people to buy goods or services from others (Gregory \& Reis, 2007). Money has several functions such as a medium of exchange, a unit of calculation, and storage of value or purchasing power. In its function as a means of exchange, humans also use it as a tool of value to measure the selling and buying price of goods in economic activities. The exchange rate can be used as a tool to measure a country's economic condition.

It shows the increase in the exchange rate of the rupiah over the US dollar. In the sharia financial system, the financial strength can be seen from the development of the economic system influenced by several factors such as good financial performance. Many exports and imports made by the government becomes the state's income. The income is greater than the state expenditure. The strengthening of the rupiah exchange rate that occurred in December 2014 was Rp. 12,410.00, and the movement of the economy of other countries experienced very good performance, it 
caused the rupiah exchange rate decreased. The strengthening of the rupiah exchange rate is influenced by the good growth of the American economy and the influence of rising interest rates. As said by Muhammad Yusuf as the staff of Bank of Indonesia:

"Economic growth in 2014 was very slow, so the economic growth in Indonesian decreased. It happened due to lack of real demand and decline of food prices, coal prices, commodity prices, and world oil prices. So, the consequence of slow economic growth makes currency exchange rate decrease".

In 2016, the rupiah exchange rate moves steadily and tends to strengthen in 2016. The strength of the rupiah lasted until October and kept stagnant in November 2016 amounting Rp. 13,550 after the presidential election of the United States. Rupiah strengthened by $1.70 \%$, it was lower than the previous year, in addition, the volatility of the rupiah value is also lower when compared with the average currency volatility of the countries like Lira Turkey, South African Rand, Brazilian Real, and Malaysian Ringgit.

Strengthening of state financial value toward rupiah exchange rate is supported by positive sentiment of domestic economy along with macroeconomic stability condition. It is maintained and implemented with tax law that runs well and smoothly. However, in November 2016 the strengthening of the exchange rate of rupiah currency was stagnant due to increasing of global economic uncertainty after the United States election. In December 2016 the Rupiah Exchange Rate was Rp. $13,436.00$. It increased due to the flow of foreign funds. Bank of Indonesia will continue to be aware of the risk of capital reversal due to foreign policy uncertainty.

The Exchange Rate of Rupiah toward BI Rate

Table 2. BI Rate 2012-2016

\begin{tabular}{lrrrrr}
\hline Month & $\begin{array}{r}2012 \\
(\%)\end{array}$ & $\begin{array}{r}2013 \\
(\%)\end{array}$ & $\begin{array}{r}2014 \\
(\%)\end{array}$ & $\begin{array}{r}2015 \\
(\%)\end{array}$ & $\begin{array}{r}2016 \\
(\%)\end{array}$ \\
\hline Jan & 6 & 5,75 & 7,50 & 7,75 & 7,25 \\
Feb & 5,75 & 5,75 & 7,50 & 7,50 & 7,00 \\
Mar & 5,75 & 5,75 & 7,50 & 7,50 & 6,75 \\
Apr & 5,75 & 5,75 & 7,50 & 7,50 & 6,75 \\
May & 5,75 & 5,75 & 7,50 & 7,50 & 6,75 \\
Jun & 5,75 & 6,00 & 7,50 & 7,50 & 6,50 \\
Jul & 5,75 & 6,50 & 7,50 & 7,50 & 6,50 \\
Aug & 5,75 & 7,00 & 7,50 & 7,50 & 5,25 \\
Sep & 5,75 & 7,25 & 7,50 & 7,50 & 5,00 \\
Oct & 5,75 & 7,25 & 7,50 & 7,50 & 4,75 \\
Nov & 5,75 & 7,50 & 7,75 & 7,50 & 4,75 \\
Dec & 5,75 & 7,50 & 7,75 & 7,50 & 5,50 \\
\hline Souce
\end{tabular}

Source of Data: Bank of Indonesia 2016

$\mathrm{BI}$ Rate is an interest rate determined by Bank of Indonesia. Increasing or reducing $\mathrm{BI}$ rate is on of monetary policies. BI rate has a very important rule to affect the flow of capital and the exchange rate of rupiah. It happens because some investors look for countries with profitable interest rates. If domestic BI rate is low, it will influence the flow of capital and also money exchange rate that finally gets in to foreign 
country. And if BI rate is high, it will encourage foreign capital gets into domestic country. If Indonesia gets a lot of capital, the bid of US dollar will increase. It tends to increase the exchange rate of US dollar. It is described on the table of BI rate in 20122016 at Bank of Indonesia as Table 2. From the table of BI rate above from 20152016, it can be known that in January 2014 BI rate was 7,50\%, and it lasted until December 2015. It has bad impact on Indonesia's economic growth and the exchange rate increase over the US dollar. Since the global economy is growing slow, it influences the economic growth of Indonesia, and it caused the rupiah exchange rate decreased over the US dollar. The decline of Indonesia economy was influenced by low export due to the demand for money. As stated by the staff of Bank of Indonesia, Abdul Haris:

"The pressure of rupiah exchange rate is affected by uncertain increase of EFR and increasing the exchange rate of Yuan until November 2015. During that time, Indonesia experienced the impact of inflation. The exchange rate of rupiah decreased $11,05 \%$, so rupiah exchange rate against US dollar reached Rp. 13.351 in November".

The Table 2. also describes that Islamic finance growth decreased by 0,25 from 7,50 to 7,25 in January 2016. The decline of inflation in Indonesia was due to slow economy growth influenced by the weakening of world economy. In February the BI rate was $7 \%$, and the inflation in June was $6,50 \%$, it decreased because the world economic growth was not well spread, and money market was unstable. It was the impact of economic growth in developed countries was slow except US. The raising of Fed Fund Rate may influence the performance of Islamic monetary from rupiah exchange rate. The strengthening of man power and economy performance in India and China influences the economy growth. Indonesia economy increased and might lead to press the level of inflation value toward Islamic monetary performance. As said by the staff of Bank of Indonesia, Anita Pratiwi:

"Indonesia economy increased during February until July. It can overcome the level of inflation influenced by some factors, so the exchange rate of rupiah increased over the US dollar. Indonesia's economy growth in 2016 was 5,0\%, while in 2015 was $4,8 \%$, so it grew well".

Since early December 2016, rupiah exchange rate strengthened since there were lots of foreign investors came to Indonesia. Bank of Indonesia will always be aware of the risk of capital reversal that may happen concerning uncertain America policies in the future. The result of data analysis above showed that Islamic finance system in 2016 was affected by economy growth amounted 5\%.

\section{CONCLUSION}

Inflation is a process of increasing the prices of goods continuously. In 2013 the inflation raised, it was $8,38 \%$. And in 2014 the inflation level was $8,36 \%$. This case influenced the performance of Islamic finance affected by the raising of world oil price, fuel, electricity tariff, transportation fare, and staple food. The declining of coal price, palm oil, rubber, and the rising of chili price affected rupiah exchange rate, and US dollar exchange rate increased. In January 2015 the inflation rate was 6,96\%, and 7,18\% in August. It occurred due to the world economic growth in small and big countries was slow. It was also the impact of inflation. In January 2016 the inflation 
level was $4,14 \%$, and 3,35\% in December. As a result, the performance of Indonesia monetary in perspective of Islamic finance was getting better.

Money is one of important exchange rates in economic sector around the globe. Money is a series of asset used regularly by people to buy goods or services from others. Money has several functions such as a means of exchange, unit of counting, value storage or purchasing power, etc. In January 2012 the rupiah exchange rate was Rp. 9.014, and in December 2013 was Rp. 12.169. This was some impacts of low rupiah exchange rate as compared with US dollar. And it affected the performance of state monetary in the perspective Islamic finance. In 2014 the rupiah exchange rate was Rp.13.835 and in 2015 was Rp. 14.399.

BI Rate is interest rate determined by Bank of Indonesia. Increasing or reducing $\mathrm{BI}$ rate is one of monetary policies. The purpose of establishing Islamic finance is to measure BI rate performance in Indonesia economy system toward inflation. Bi Rate played a very important rule to influence the capital flow and rupiah exchange rate since some investors probably would look for some countries with profitable interest rate.

\section{REFERENCES}

Adek L, Oktavia, at al. (2013). Analisis Kurs dan Money Supply di Indonesia. Jurnal Kajian Ekonomi, 1(2)

Chapra, M.U. (1996). Monetary Management in An Islamic Economy. Islamic Economic Studies.4(1)

Choudhury, M. A. \& Hussain, M. M. (2005). A Paradigm of Islamic Money and Banking. International Journal of Social Economics. 32(3).

Hasan, A. al-Awraq al-Aqdiyah fi al-Iqtishad al-Islami, terj. Saifurrahman Barito dan Zulfakar Ali.

Hatta, M. (2008). Telaah Singkat Pengendalian Inflasi dalam Perspektif Kebijakan Moneter Islam. Jurnal Ekonomis Ideologis.

Huda, N., et. al. (2009). Ekonomi Makro Islam Pendekatan Teoritis. Jakarta: Kencana Prenada Media Group.

Idrus, M. (2007). Metode Penelitian Ilmu Sosial. Yogyakarta: Erlangga.

Mankiw, N.G. \& Reis, R. (2007). Sticky Information in General Equilibrium. Journal of the European Economic Association, 5(2-3), 603-613

Mannan, M.A. (2008). Abstract of Researches in Islamic Economics. Jeddah: King Abdul Aziz University.

Margono, S. (2005). Metodologi Penelitian Pendidikan. Jakarta: Rineka Cipta.

Nadzir, M. (1999). Metode Penelitian. Jakarta: Ghalia Indonesia.

Nopirin. (2007). Ekonomi Moneter. Yogyakarta : BPFE-Yogyakarta.

Sartono, A.R. (2003). Manajemen Keuangan Internasional. Edisi ke-5. Jakarta: Erlangga.

Serfianto, R. et al. (2013). Pasar Uang dan Pasar Valas. Jakarta: PT Gramedia Pustaka.

Situmeang, C. (2010). Manajemen Keuangan Internasioanal. Bandung: Citaputaka Media Perintis

Soekanto, S. (1994). Sosiologi Suatu Pengantar. Jakarta: Raja Grafindo Persada.

Thobarry, A. (2009). Analisis Penagaruh Nilai Tukar Suku Bunga, Laju inflasi dan Pertumbuhan GDP Terhadap Indeks Harga Saham Sektor Properti. Tesis. Semarang: Universitas Diponegoro

Waljianah, R. \& Wulandari, F. (2013). Determinasi Tingkat Suku Bunga Perbankan di In- 
donesia (Periode Juli 2005 - Desember 2011). Jurnal Ilmiah, Universitas Brawijaya Malang.

Websites:

http://arfendios.blogspot.com/2013/2008/apa-itu-nilai tukar.html

http://apriliani’s.blogspot.com/2015/dampak lemahnya nilai tukar rupiah terhadap dollar AS perekonomian indonesia. 